\title{
大規模商業施設における新型コロナウイルス感染症の影響による 買物行動の変化に関する研究

\author{
A STUDY ON CHANGES OF SHOPPING BEHAVIOR UNDER THE INFLUENCE OF NOVEL \\ CORONAVIRUS INFECTION IN A LARGE-SCALE COMMERCIAL FACILITY
}

\author{
高橋彰*1, 大阪 直 也 ${ }^{* 2}$, 安 福 健 祐*3, 阿 部 浩 和*4 \\ Akira TAKAHASHI, Naoya OSAKA, Kensuke YASUFUKU \\ and Hirokazu $A B E$
}

\begin{abstract}
The purpose of this study is to quantitatively understand how shopping behavior trends have changed due to the influence of COVID19 by using the purchase history of membership cards in the large-scale commercial facilities. The main findings are as follows. In 2020 , under the influence of COVID-19, the number of shoppers and purchases decreased, and the number of visits decreased by more than $20 \%$ in areas far from the subject shopping center. The average length of time spent in the shopping center showed a difference in trend depending on distance from the target facility and age.
\end{abstract}

Keywords : COVID-19, Shopping behavior, Large-scale commercial facility 新型コロナウイルス感染症, 買物行動, 大規模商業施設

\section{1. はじめに}

新型コロナウイルス感染症（以下 COVID-19）の流行は、大きく 人々の生活習慣や常識を変化させた。低迷した国内消費を喚起する ため国は新型コロナウイルス感染症緊急経済対策として Goto キャ ンペーンなどの国内旅行やイベント開催に対する規制を緩和する対 策を打ち出したが、2021 年 1 月 7 日には首都圈の 1 都 3 県に再び 緊急事態宣言が出されるなど、先の見通せない状況が継続している。 経済産業省文1) は、消費活動について COVID-19 の影響により外出 自肃の中で全体的に抑制されているものの、COVID-19 の感染拡大 は近年のデジタル経済の拡大を加速させており、2020 年 3 月以降 に電子商取引の拡大が顕著に見られる中で、デジタルを活用した消 費活動が対面での経済活動の制約を補完する関係になっていると指 摘している。また、日本ショッピングセンター協会文 ${ }^{2}$ にによると、 対面型販売であるショッピングセンター (以下 SC) の 2020 年の売 上高は、前年比で $20 \%$ 以上落ち込むなど難しい経営局面を迎えてい る。

実店舗を持つ商業施設においては、買物動線長が非計画購買個数 に影響することが知られている文 3 。 。動線的にも時間的にもより長く

*1 大阪大学サイバーメディアセンター 特任助教 (常勤) ・博士 (工学)

*2 大阪大学大学院工学研究科地球総合工学専攻 大学院生 - 学士 (工学)

*3 大阪大学サイバーメディアセンター 准教授・博士（工学）

*4 大阪大学サイバーメディアセンター 教授・博士 (工学)
店舗内に滞在させる仕掛けによって非計画購買を誘発することが対 面型販売の強みの一つと認識されており、商業施設内の回遊行動を 促す空間構成やテナント配置が重視される傾向にある文4)。しかしな がら、COVID-19 の影響により利用者の買物心理や買物行動に变化 が起きていると考えられ、回遊行動を誘発する仕掛けやキャンペー ンを実施することで買物動線と滞在時間を延ばすという従来の戦略 から COVID-19 に対応した新しい購買誘発戦略が求められている。 また、このような買物行動の変化を把握することは、商業的側面だ けでなく建築計画においても重要であると考えられる。

店舗内の買物行動を分析した研究として、長澤ら文 5) は大型商業 施設で買物行動を追跡調查し、その行動特性を明らかにした上で、 目的地の有無によって異なる経路選択を行うことで、時系列的に状 態が変化する行動モデルを再現している。しかし、行動モデルの精 度を高めるためには、行動調査データを増や寸必要があり、実際の 買物客を対象としたデータの収集には限界がある。これに対して、 建築・都市計画の分野では ICT 技術やビックデータの利用によって、 改修を含む設計段階や施設配置の影響評価などにおいて人間行動の 特性を把握した上で、空間性能評価を行うアプローチが期待されて

Specially Appointed Assist. Prof. (full time), Cybermedia Center, Osaka Univ., Dr.Eng.

Division of Global Architecture, Graduate School of Engineering, Osaka Univ., B.Eng.

Assoc. Prof., Cybermedia Center, Osaka Univ., Dr.Eng.

Prof., Cybermedia Center, Osaka Univ., Dr.Eng. 
いる文6）。Hui ら文7）は RFID（Radio Frequency Identification）と 呼ばれる買物かごについた IC タグと無線交信による自動認識シス テムにより、スーパーマーケットにおける 1000 以上の動線データ をもとに、売場滞在時間と店舗内行動の関倸についてモデルを構築 し、店舗内滞留時間が長くなると、購買意欲が高まることを指摘し ている。ただし、ここでは買物かごについた IC タグを追跡してい るため、買物かごをあまり用いない百貨店やショッピングセンター では適用が難しい。さらに、石垣ら文 8) は、顧客属性データを含む 百貨店 POS（Point Of Sale）データ 1200 万件以上のレコードを用 いて、買物客の店舗内購買行動を空間的視点から分析している。た だし、ここではフロア間推移確率を算出し、顧客属性要因とともに 統計的に分析しているものの、テナント間の分析までは行っていな い。

以上の先行研究において、追跡調査では調査員が買物客の商業施 設内の動きに合わせて追跡するため、施設内の詳細な行動データを 得ることができる一方で、大規模な SC や百貨店では買物客の滞在 時間も長く調查コストが大きくなるなどの課題がある。また、 COVID-19の影響下では感染リスクなどを考慮すると現地調查は現 実的に難しい。一方で、商業施設内の買物行動について COVID-19 の影響を分析した研究は希少であるため、現地調查によらない POS などのビックデータを用いた買物客の行動分析は COVID-19 の影 響下における買物行動モデル作成に向けた基礎的データとして意義 があると考えられる。

本研究は大規模商業施設の一つである $\mathrm{SC}$ を対象として、会員力 ードの購入履歴を利用することで、COVID-19 禍による買物行動の 変化を定量的に把握し、COVID-19 影響下における商業施設計画に 必要な買物客の特性を明らかにする。

\section{2. 方法}

Fig.1 に対象 SC の平面図を示す。対象とする商業施設は大阪市 阿倍野区に位置し、店舗数約 240 、店舗面積約 $69,000 \mathrm{~m}^{2}$ 、地上 4 階 地下 1 階建ての大規模 $\mathrm{SC}$ である。各店舗には番号を振り、共通通 路部分は灰色で示している。店舗番号は 1-209 および 301-336 の範 囲で設定しており、店舗入れ替え、期間限定店舗、2020 年は COVID19 の影響で欠番になっているものもある。また、Fig.1の一点鎖線 の範囲は核店舗を示しているが、核店舗は今回入手できた会員カー ドデータ（以下、MC) の対象外となっているため分析に含んでいな い。

次に、Table1 に利用した MC の概要を示す。2019 年と 2020 年 の 5-9 月の各 5 ケ月間注 ${ }^{1}$ の $\mathrm{MC}$ による各店舗の購入履歴データ であり、総データ処理数は約 310 万件、購入履歴には、会員番号、 性別、年齢、住所、店舗名、購入日時、購入金額などの 23 項目が含 まれている注 2)。また、MC の処理数は 1 ケ月間にお抢よそ 27 万一 38 万件あり、 8 万 -10 万人の会員の購入履歴を利用することがで きる。ここから SC 利用者の COVID-19 における買物行動の変化の 傾向を把握することを試みる。最初に買物客数、買物回数の変化に ついて、月毎で前年比変化を概観し、年齢と対象施設からの距離に よる買物傾向を分析する。 SC からの距離については、 $\mathrm{MC} の$ 登録住 所を対象施設が立地する阿倍野区を中心として、行政区によって距 離エリアを 5 段階で設定した注3）（Fig.2）。
次に、 $\mathrm{SC}$ 内の買物行動について、滞在時間と店舗間遷移回数を分 析する。ここで、実際の滞在時間は入店した時間から退店した時間 であるが、本研究では推定不可能であるため、 $\mathrm{MC}$ の購入履歷があ る店舗間に着目し、最後に購入した時間から最初に購入した時間の 差を疑似的な滞在時間と仮定している。Fig. 3 は買物客の買い回り 行動の例を模式的に示したものであるが、\#\#1の場合は 1 店舗の 情報しかないため、滞在時間を求めることはできず、\#\#\#3 の場合 のように入退館時間における滞在時間が短くなるケースも考えられ る。

Table1 MC data Information

\begin{tabular}{ll}
\hline Type & $:$ Purchase history of membership card \\
\hline Date & $:$ May-September 2019, May-September 2020 \\
\hline Items & $\begin{array}{l}23 \text { items including membership number, gender, age, } \\
\text { address, store name, purchase date and time, purchase }\end{array}$ \\
\hline Number of data $:$ & $3,136,559$ (Number of record data for all months) \\
\hline
\end{tabular}
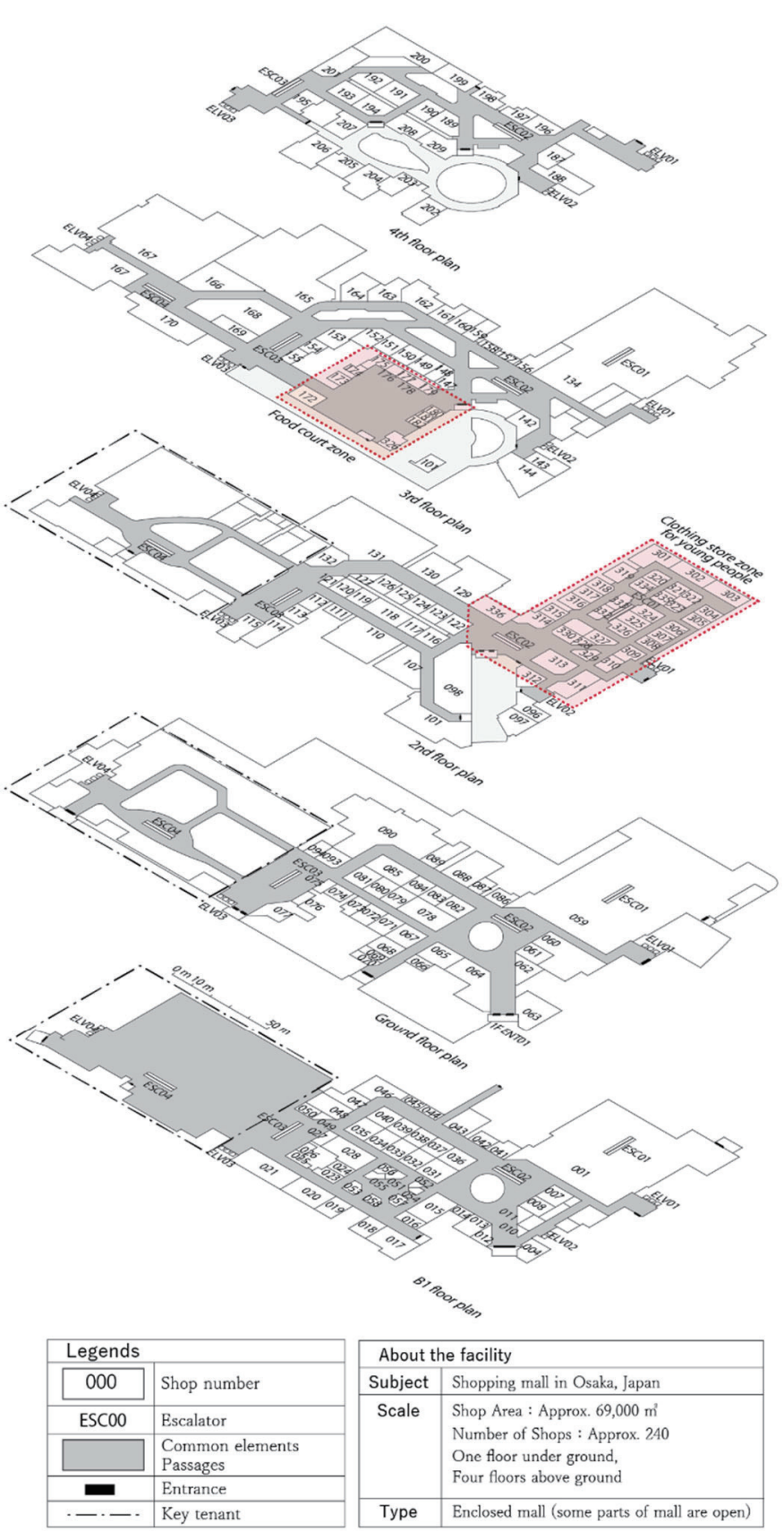

\begin{tabular}{|c|l|}
\hline \multicolumn{2}{|c|}{ About the facility } \\
\hline Subject & Shopping mall in Osaka, Japan \\
\hline Scale & $\begin{array}{l}\text { Shop Area : Approx. 69,000 m } \\
\text { Number of Shops : Approx. 240 } \\
\text { One floor under ground, } \\
\text { Four floors above ground }\end{array}$ \\
\hline Type & Enclosed mall (some parts of mall are open) \\
\hline
\end{tabular}

Fig. 1 Plan of the SC 


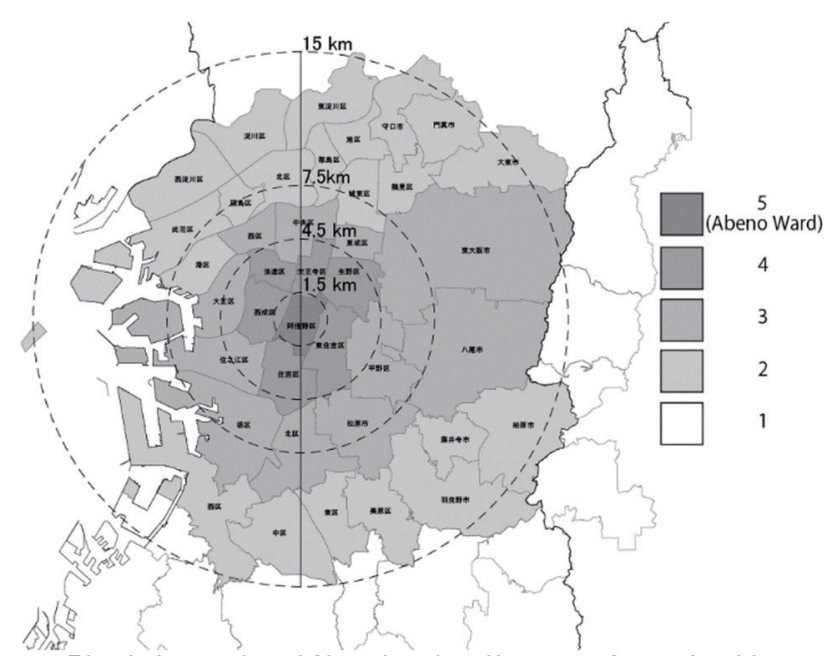

Fig. 2 Area classification by distance from the SC

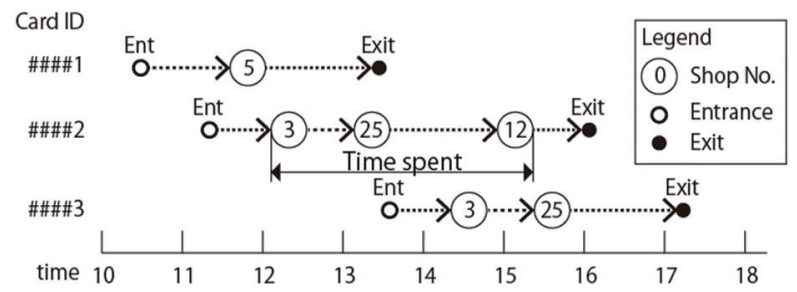

Fig. 3 Examples of customer's transition between stores

しかしながら、1 回の来訪で 2 店舗以上の購入履歴がある利用者は 2019 年（6-9 月）で約 34 万件 ( $42 \%) 、 2020$ 年（6-9 月）で約 27 万件 $(39 \%)$ あるため、統計的に滞在時間を分析することで買物客 が店舗内で過ごした時間の増減傾向を読み取れると考える。

店舗間遷移回数は、「ある会員が店舗 $i$ で購入して次に店舗 $\mathrm{j}$ で購 入した履歴の合計 $\left(N_{i, j}\right) 」$ を各店舗間で求めている。つまり、2 店舗 間の遷移に関して出発店舗と目的店舗の関係のみを抽出し、定量化 する。例えば、Fig.3 の\#\#\#2 の場合、最初の遷移では出発店舗が店 舗 3 で目的店舗は店舗 25 となり、次の遷移では、出発店舗が店舗 25 で目的店舗は店舗 12 となるが、店舗 $3 \rightarrow$ 店舗 25 、店舗 $25 \rightarrow$ 店 舗 12 のそれぞれを 1 回として数える。

データ加工および分析にはプログラム言語の Python3.9 と Python 用データ解析オープンソースライブラリ Pandas および統 計解析ソフト EZR 1.5 文9) を利用した。

\section{3. 結果}

\section{1 買物客の消費傾向}

Table 2 に 2019 年と 2020 年の 6-9 月の MC を利用した買物客 の概要を示寸。以下、分析結果は全て対象期間である 2019 年と 2020 年の 6-9 月に MC を利用した買物客についての分析結果を示して いる。2020 年と 2019 年を比較すると、買物客の平均年齢は 40 代 前半、女性が約 9 割を占める構成に大きな変化は見られないが、男 性客数は前年比 $98 \%$ 、女性客は $91 \%$ で女性客の減少割合が大きく なっている。 SC を訪れて MC を使用した買物客数注 ${ }^{4}$ は は $92 \%$ 、総 売上は $84 \%$ に減少している。平均買物回数注 5 は は $91 \%$ 、総買物回数 は $83 \%$ でともに減少している。また、1 回の買物の客単価は前年比 93\%、6-9 月の 4 ケ月間に使用した客単価は $92 \%$ とまり差は見
られなかった。

次に、月毎の買物客の消費行動の傾向を見ていく。Fig.4 は MC を 利用して買い物をした各月の買物回数と買物客数を表している。こ れによると、買物客数および買物回数は緊急事態宣言が解除されて 本格的に営業を再開した 2020 年 6 月には前年比並みに一旦戻って いるが、7-9 月は前年比で約 $20 \%$ 減少している。

Fig.5 は客単価の変化を示している。1 回の買物の客単価と 1 ケ 月間の客単価では、 $7-9$ 月は同様の傾向を示しているが、 6 月は 1 回の客単価はほとんど変わらないのに対し、月の客単価は 2020 年 の方が約 $12 \%$ 減少している。これは、2020 年の 6 月の時点では外 出自肃の心理が働いたため、1 人当たりの店舗を訪れる回数が少な くなったことで、 1 人当たりの月の支払い金額が抑えられたことが 考えられる。

Table2 Overview of member customers

\begin{tabular}{|c|c|c|c|c|c|c|c|c|}
\hline Date & Gender & $\begin{array}{c}\text { No. of } \\
\text { customers }\end{array}$ & $\begin{array}{l}\text { Average } \\
\text { age }\end{array}$ & $\begin{array}{l}\text { Average } \\
\text { number of } \\
\text { purchases }\end{array}$ & $\begin{array}{c}\text { Total } \\
\text { number of } \\
\text { purchases }\end{array}$ & $\begin{array}{l}\text { Average } \\
\text { amount } \\
\text { from one }\end{array}$ & $\begin{array}{c}\text { Average } \\
\text { spend } \\
\text { per }\end{array}$ & $\begin{array}{c}\text { Total } \\
\text { sales } \\
\text { (Jun-Sep) }\end{array}$ \\
\hline & & (people) & (age) & (times) & $\begin{array}{l}\text { purchases } \\
\text { (times) }\end{array}$ & $\begin{array}{l}\text { shopping } \\
\text { (Yen) }\end{array}$ & $\begin{array}{l}\text { customer } \\
\text { (Yen) }\end{array}$ & $(10,000$ \\
\hline \multirow[t]{4}{*}{ 2019(Jun-Sep) } & female & 148,460 & 43.0 & 7.8 & $1,155,984$ & 3,739 & 25,314 & 375,814 \\
\hline & male & 18,072 & 45.4 & 6.2 & 111,260 & 4,993 & 24,519 & 44,310 \\
\hline & unknown & 319 & 55.7 & 7.4 & 2,356 & 3,001 & 19,777 & 631 \\
\hline & total & 166,851 & 43.3 & 7.6 & $1,269,600$ & 3,874 & 25,217 & 420,755 \\
\hline \multirow[t]{4}{*}{ 2020(Jun-Sep) } & female & 135,150 & 43.8 & 7.1 & 958,923 & 3,476 & 23,361 & 315,728 \\
\hline & male & 17,742 & 46.2 & 5.6 & 98,570 & 4,678 & 21,987 & 39,009 \\
\hline & unknown & 282 & 57.1 & 7.4 & 2,099 & 20,052 & 20,065 & 565 \\
\hline & total & 153,174 & 44.1 & 6.9 & $1,059,592$ & 3,614 & 23,196 & 355,303 \\
\hline $2020($ Jun-Sep)/ & female & $91 \%$ & $102 \%$ & $91 \%$ & $83 \%$ & $93 \%$ & $92 \%$ & $84 \%$ \\
\hline 2019(Jun-Sep) & male & $98 \%$ & $102 \%$ & $90 \%$ & $89 \%$ & $94 \%$ & $90 \%$ & $88 \%$ \\
\hline \multirow{2}{*}{ (\%) } & unknown & $88 \%$ & $102 \%$ & $101 \%$ & $89 \%$ & $668 \%$ & $101 \%$ & $90 \%$ \\
\hline & total & $92 \%$ & $102 \%$ & $91 \%$ & $83 \%$ & $93 \%$ & $92 \%$ & $84 \%$ \\
\hline
\end{tabular}

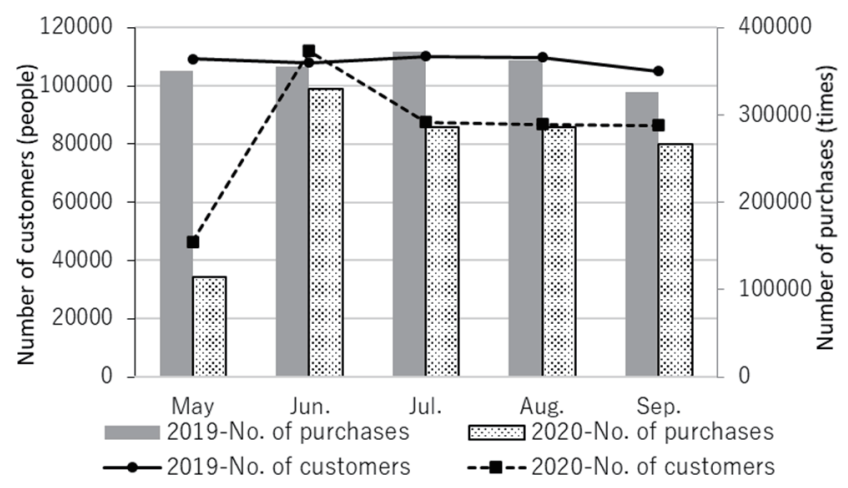

Fig. 4 Total number of customers and total number of purchases at the SC in each month

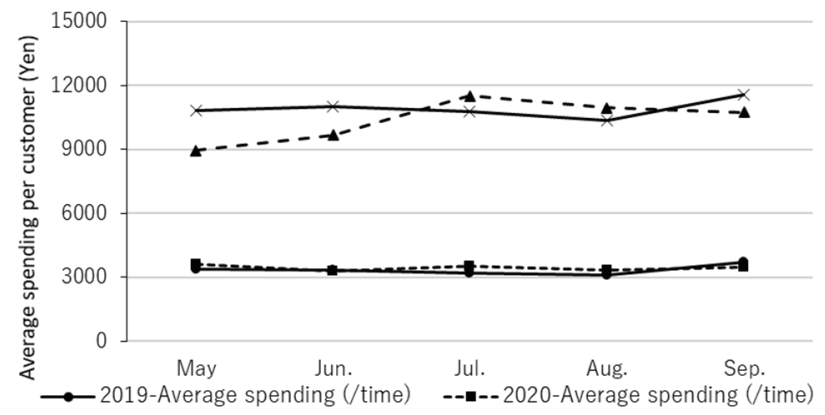

—2019-Average spending (/month) - - -2020-Average spending (/month) Fig. 5 Changes in average spending per customer (per time and per month) 


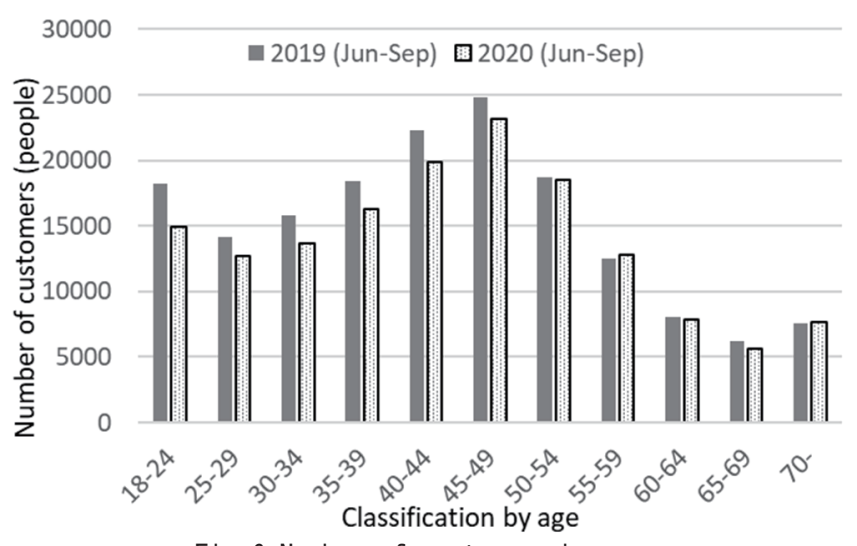

Fig. 6 Number of customers by age

Fig.6 は 2019 年と 2020 年の年齢別買物客数を示しているが、こ れによると、50 代以下の年齢区分では COVID-19 で買物客数が減 少傾向であるのに対して、50 代以上の年齢区分では、両年において ほとんど変化が見られなかった。

2020 年と 2019 年の月毎の比較から、2020 年 6 月は緊急事態宣 言の活動自肃明けで、買物客数が一旦戻ったが $7-9$ 月は前年比約 $20 \%$ 減となっており、年齢別では 50 代以上の買物客の方が 50 代以 下よりも COVID-19 の影響が少ないことが示唆された。50 代以下 の影響が大きかった理由として、対象 SC は都心近傍に立地してお り、多くの鉄道駅に隣接し、バス路線も複数あることから、通勤・ 通学の途中で多くの買物客が利用していると考えられるが、1 回目 の緊急事態宣言（2020 年 4 月 7 日）以降、政府の要請により、多く の企業や教育機関でテレワークが実施されたため、通勤・通学買物 客の来店が減ったことなどが考えられる注6)。

\section{2 対象施設から距離による買物傾向の変化}

Fig.7 は Fig.2 による対象施設からの距離でエリア分けした月別 の買物客数の構成割合を示している（以下、「エリア」は対象施設か らの距離によるエリア分けを表す)。これを見ると、2019 年は各月 にほとんど差は見られない。2020 年は 2019 年と比較すると、6月 は差がみられないが、7-9 月はエリア 5、4 の対象施設近傍のエリ アの構成割合が $2-5 \%$ 上がり、エリア $2 、 1$ が逆に $3-4 \%$ 下がって いる。

Fig.8、Fig.9 は 2019 年と 2020 年の買物客数の年齢別エリア構成 比を示している。両年とも年齢区分が高くなるにつれて、近隣の買 物客数の構成比が増加する傾向があり、特に全体の傾向と比較して も55 歳以上より段階的にその傾向は大きくなっている注 7)。また、 30 歳未満の若い世代は、遠方エリア 1 、2 からの構成比が他の世代 と比較すると大きい傾向があり、30 歳から 50 歳までの区分は似た 傾向を示している。また、2020 年と 2019 年で買物客数の年齢別エ リア構成比は前年比でエリア 1 がわずかに減少しているがほとんど 傾向に差はほとんど見られなかった。

次に、 $\mathrm{SC}$ への来訪回数注 8 を見ていく。Fig.10 の棒グラフは 2019 年と 2020 年の $\mathrm{SC}$ への月平均来訪回数（SC）をエリア別で示し、 折れ線グラフは 1 人当たりの月平均来訪回数（1 人）をエリア別で 示している。これを見ると、月平均来訪回数 (SC) は対象施設に近 いエリア 5、4、3 はエリア $2 、 1$ に比べ約 $2-3$ 倍多くなっている。

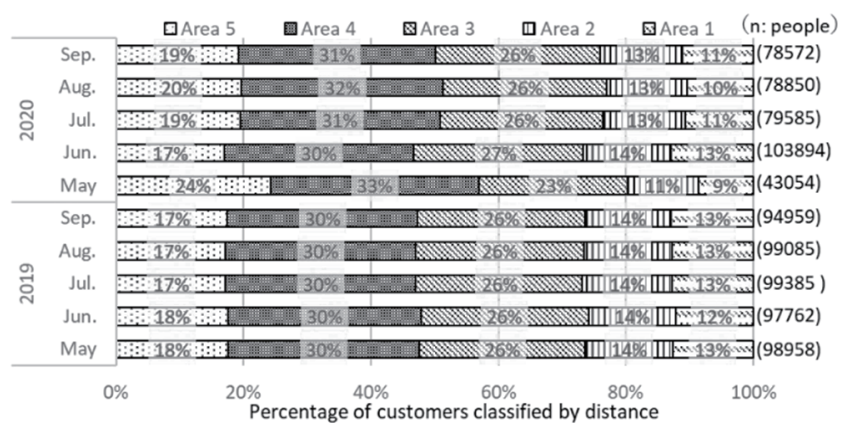

Fig. 7 Percentage of customers classified by distance in each month

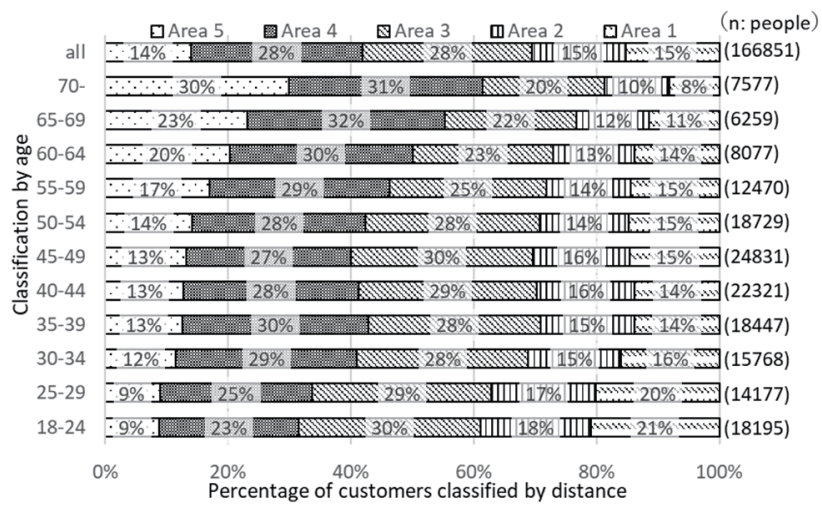

Fig. 82019 (Jun-Sep) - Percentage of customers classified by distance and age

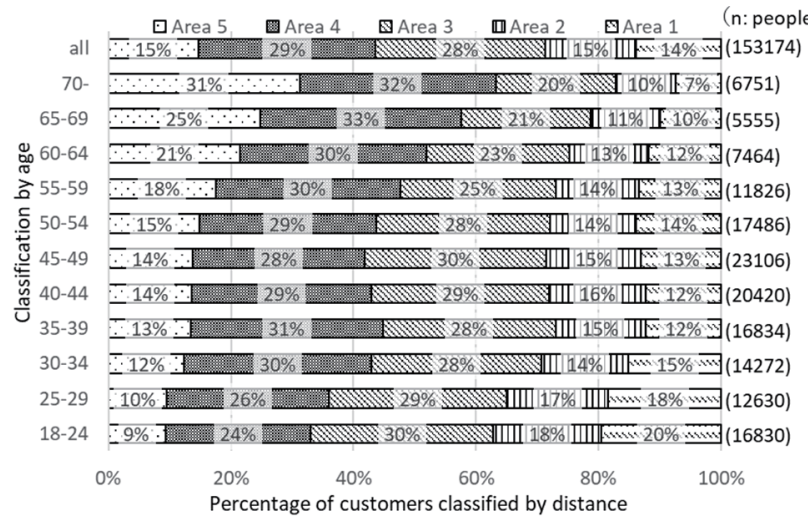

Fig. 92020 (Jun-Sep) - Percentage of customers classified by distance and age

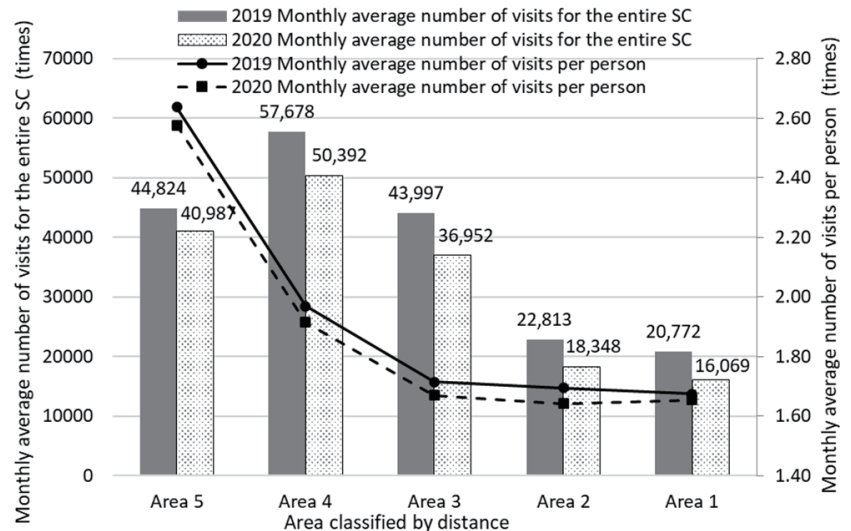

Fig. 10 Monthly average number of visits classified by distance for the entire SC and per customer 
また、月平均来訪回数（1 人）は、対象施設に近いエリアほど多く なっており、エリア 5 は最も多く 2019 年 $2.64 、 2020$ 年 2.58 、次 いで、エリア 4 は 2019 年 $1.97 、 2020$ 年 1.92 となっている。エリ ア 3、2、1 に関しては 2019 年 1.71-1.67、2020 年 1.67-1.65 でエ リア 5、4 と比べるとその差は小さく、同様の傾向を示している。一 方で、2020 年と 2019 年を比較すると、月平均来訪回数（SC）の前 年比についてエリア 1 は 77\%、エリア 2 は $80 \%$ 、エリア 3 は $84 \%$ 、 エリア 4 は $87 \%$ 、エリア 5 は $91 \%$ とエリアが遠くなるほど減少割 合が大きくなっている。また月平均来訪回数（1 人）はどのエリア でも減少しているものの、減少回数は 0.02-0.06 で大きな差は見ら れなかった。

以上より、2020 年前年比の買物客数は 7-9 月で対象施設近傍の エリア $5 、 4$ の構成割合が $2-5 \%$ 増加し、逆にエリア $2 、 1$ は $3-$ $4 \%$ の減少が見られる一方で、エリア区分と年齢区分による傾向の 差はあまり見られなかった。月平均来訪回数（SC）はエリアが遠く なるほど減少割合が大きく、エリア 1 、 2 は $20 \%$ 以上減少している。 一方で、月平均来訪回数（1 人）に大きな差は見られなかったこと から、エリアが遠いほど買物客数の減少割合も大きく、COVID-19 の影響が大きいことが示唆された。これについても、テレワークの 拡大により、都心几通勤・通学する人が減少したことで、途中で対 象 SC を利用寸る人が減少したことが考えられ、2020 年 7-9 月は 新規感染者数が増加傾向にあったため、特に、遠いエリアほどその 影響が強かったと推察される注 1,6 。

\section{3 SC 内買物行動の変化}

Fig. 11 は 1 回の来訪での平均買い回り店舗数（月毎）を示してい る。2020 年と 2019 年の各月を比較すると、2020 年 6-8 月は減少 傾向にあり、特に 6 月は 1.64 件（前年比 $93 \%$ ） と他の月と比べる と小さくなっている。一方で、 9 月はわずかに 2020 年の方が多くな つている。また、2020 年と 2019 年の 6-9 月の買い回り店舗数に ついて、マン・ホイットニーの U 検定した結果、有意差が認められ た $(\mathrm{p}<.01)$ (Table3)。

Fig.12 は 1 回の来訪における平均の滞在時間（月毎）を示してい る。 2019 年は 8 月の滞在時間が最も長く、各月でばらつきが見られ るが、2020 年はほとんど変化が見られなかった。また、2020 年と 2019 年の 6-9 月の滞在時間について、マン・ホイットニーの U 検 定した結果、有意差が認められた $(\mathrm{p}<.01)$ (Table3)。

次に、2019 年と 2020 年の各年における 6-9 各月の滞在時間に ついてクラスカル・ウォリス検定を行ったところ、 2019 年は $\mathrm{p}=2.9 \mathrm{e}-$ $18<.01 、 2020$ 年は $\mathrm{p}=0.0068<.01$ で帰無仮説は棄却された。しか しながら、2019 年の各月のペアごとの比較では、 6 月と 7 月のペア 以外に有意差が認められた (Table4)。一方で、2020 年の各月のペ アごとの比較では、 6 月と 9 月のペア $(\mathrm{p}=0.0041<.01)$ に有意差が 認められたが他のペアに有意差は認められなかった (Table5)。これ は対象施設では 2019 年 7 月初旬から 8 月中はキャンペーンセール 期間となっていること、特に 8 月は夏休み期間と調查対象期間が全 日重なっているため、家族連れや学生買物客の増加などが滞在時間 のばらつきの要因として考えられる。しかしながら、2020 年も同様 のキャンペーン注 9) が実施されたにも関わらず、滞在時間に月別の 差は 2019 年ほど認められなかった。2020 年 6 月は感染者数が少な
く、様々な自肃要請が解除されたため、一時的に買物客が増加し、 買物の滞在時間が延びた可能性がある。一方で、2020 年 7-9 月は COVID-19 の感染者数が小規模ながら増加した時期であり、 COVID-19 の影響によって、キャンペーンセールや夏休み期間とい った、買物行動に影響を与えると考えられる要因の効果が限定され ている可能性が示唆された注1)。

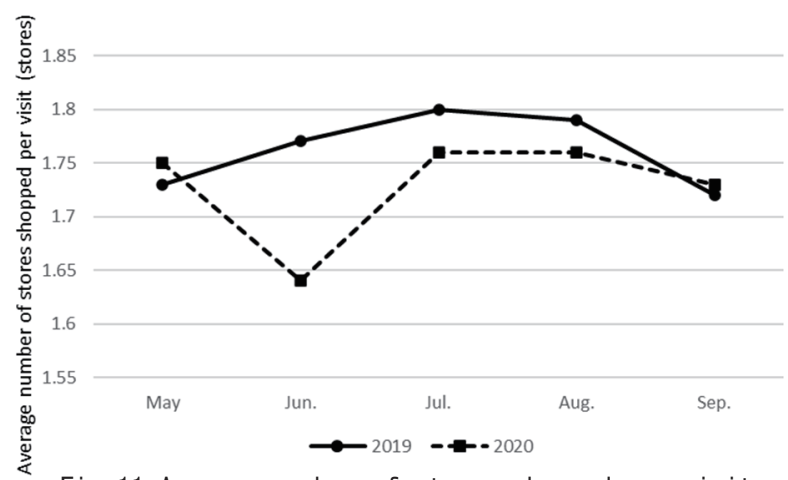

Fig. 11 Average number of stores shopped per visit in each month

Table3 Mann-Whitney U test

Number of stores shopped and time spent

\begin{tabular}{|l|cc|cc|}
\hline \multirow{2}{*}{ Year } & \multicolumn{2}{|c|}{ Number of stores shopped } & \multicolumn{2}{|c|}{ Time spent (sec) } \\
\cline { 2 - 5 } & 2019 & 2020 & 2019 & 2020 \\
\hline $\mathrm{n}$ & 824039 & 699424 & 344228 & 274395 \\
mean rank & 770924 & 750900 & 313539 & 302316 \\
$\mathrm{U}$ & $2.81 \mathrm{E}+11$ & & $4.53 \mathrm{E}+10$ & \\
lower quartile & 1 & 1 & 1080 & 1020 \\
median & 1 & 1 & 2580 & 2400 \\
upper quartile & 2 & 2 & 5580 & 5100 \\
p-value & $2.87 \mathrm{E}-221(<.01)$ & & $2.42 \mathrm{E}-104(<.01)$ \\
\hline
\end{tabular}

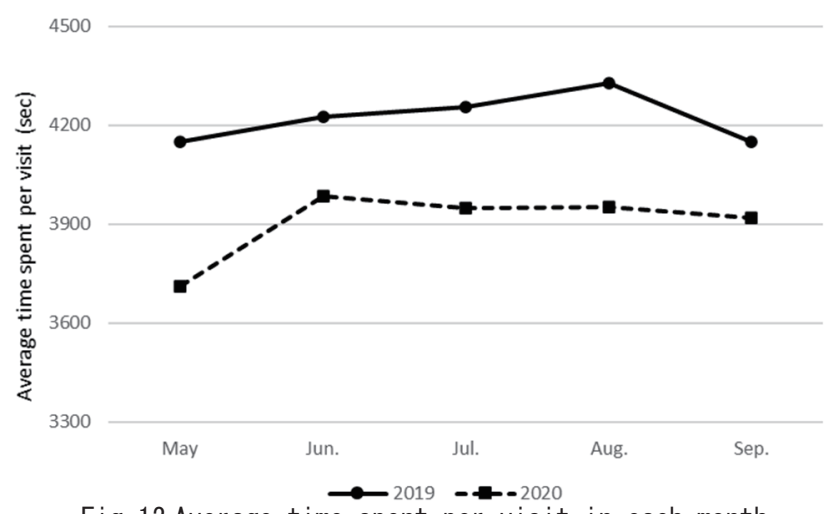

Fig. 12 Average time spent per visit in each month

Table4 2019 - P value of pairwise comparisons using Mann-Whitney U test

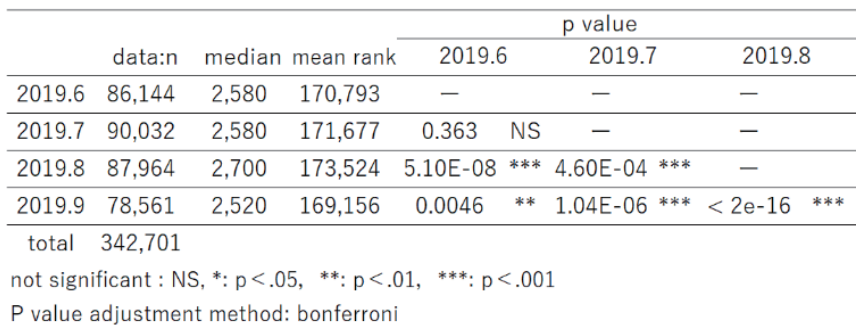


Table5 2020 - P value of pairwise comparisons using Mann-Whitney U test

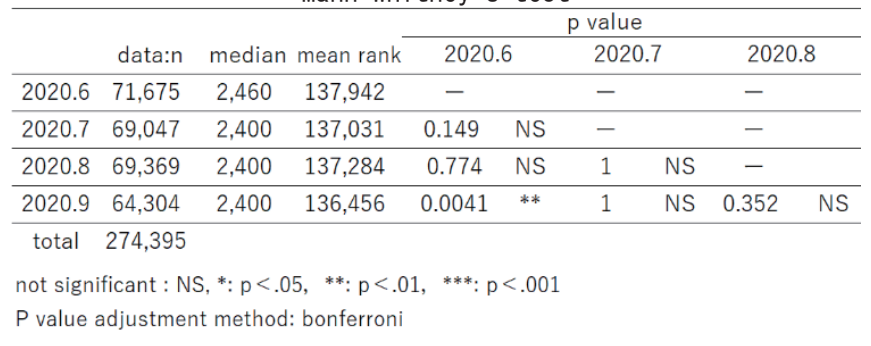

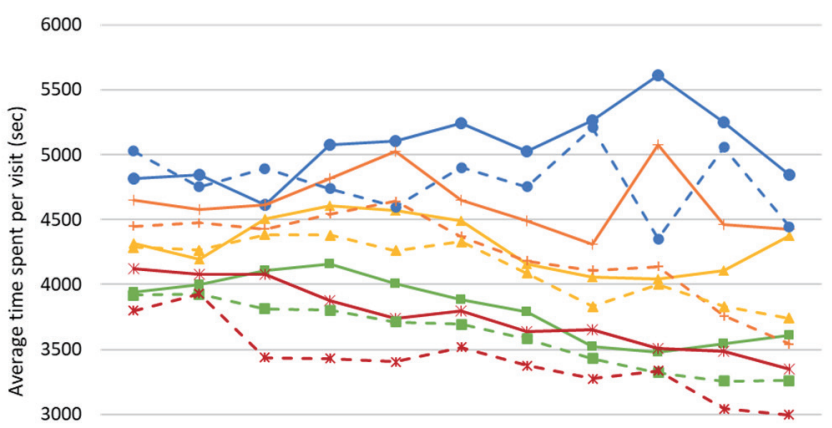

250

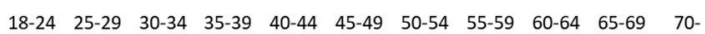
$\longrightarrow$ Area1-2019 —Area2-2019 —Area3-2019 —-Area4-2019 —

- - Area1-2020 - + - Area2-2020 - \#- Area3-2020 - - - Area4-2020 - * - Area5-2020 Fig. 13 Average time spent per visit classified by age and distance

Table6 Ratio of Average time spent per visit classified by age and distance in 2020/2019

\begin{tabular}{|c|c|c|c|c|c|}
\hline \multirow[b]{2}{*}{ (age) } & \multicolumn{5}{|c|}{ Area classification } \\
\hline & 5 & 4 & 3 & 2 & 1 \\
\hline $18-24$ & $92 \%$ & $99 \%$ & $99 \%$ & $96 \%$ & $104 \%$ \\
\hline $25-29$ & $96 \%$ & $98 \%$ & $102 \%$ & $98 \%$ & $98 \%$ \\
\hline $30-34$ & $84 \%$ & $93 \%$ & $97 \%$ & $96 \%$ & $106 \%$ \\
\hline $35-39$ & $89 \%$ & $91 \%$ & $95 \%$ & $94 \%$ & $93 \%$ \\
\hline $40-44$ & $91 \%$ & $93 \%$ & $93 \%$ & $92 \%$ & $90 \%$ \\
\hline $45-49$ & $93 \%$ & $95 \%$ & $96 \%$ & $94 \%$ & $93 \%$ \\
\hline $50-54$ & $93 \%$ & $94 \%$ & $98 \%$ & $93 \%$ & $95 \%$ \\
\hline 55-59 & $90 \%$ & $97 \%$ & $94 \%$ & $95 \%$ & $99 \%$ \\
\hline $60-64$ & $95 \%$ & $95 \%$ & $99 \%$ & $82 \%$ & $78 \%$ \\
\hline 65-69 & $87 \%$ & $92 \%$ & $93 \%$ & $84 \%$ & $96 \%$ \\
\hline 70- & $89 \%$ & $90 \%$ & $86 \%$ & $80 \%$ & $92 \%$ \\
\hline $\begin{array}{c}\text { total } \\
(2020 / 2019)\end{array}$ & $93 \%$ & $83 \%$ & 93 & & $103 \%$ \\
\hline
\end{tabular}

次に、帯在時間についてエリア区分と年齢区分の関係を見ていく。 Fig.13 は 2019 年と 2020 年の 1 回の来訪における平均滞在時間を エリア区分と年齢区分ごとに示しており、Table6 はそれを前年度比 （2020 年/2019 年）で示している。Fig.13 の中で 2019 年は実線、 2020 年は点線、同じエリア区分は同色で表現している。これを見る と、平均滞在時間は対象施設に近いエリア 5 ほど全体的に短く、遠 いエリア 1 になるにつれて長くなる傾向がある。年齢区分では、対 象施設から近くのエリアは年齢区分があがるにつれて滞在時間が短 くなり、遠いエリアでは年齢が上がるにつれて、滞在時間が長くな る傾向が見られる。2019 年と 2020 年の比較では、対象施設近傍の エリアで高年齢になるほど、滞在時間の減少率が大きく、対象施設 遠方のエリアで低年齢になるほど、滞在時間の減少率は小さくなる
傾向が見られた（Table6）。また、エリア 2 の 60 歳以上の減少率が 他と比べて大きいのは、もともと対象施設から遠いエリアの高齢者 は近いエリアの高齢者より長時間滞在する傾向であったが、 COVID-19 は高齢者や基礎疾患を持つ者は特に重症化しやすいなど の注意喚起がなされたために文 10 )、人との接触をなるべく避けよう とする心理が働いたことが考えられる注 1)。

次に、Fig.14 は縦軸に 2020 年、横軸に 2019 年における各店舗 の買物回数を示した散布図である注 ${ }^{10}$ )。準核店舗注 $\left.{ }^{11}\right)$ とそれ以外 (一 般店舗）の傾向を分析するため買物回数が 5000 回未満の散布図を 図の左上に拡大して表示し、各々の回帰直線と決定係数を図下にま とめた。ただし、各店舗を衣料品（橙色：Clothing）、雑貨（緑色： Variety）、レストランと食品（赤色 : Restaurant \& Foods）、その他

(青 : Other) の 4 カテゴリーに色分けして示している。各カテゴ リーの決定係数（ALL、＜5,000）は、衣料品(0.99、0.892)、雑貨

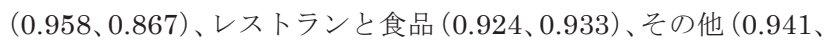
0.941）であった。また、眓中の回帰直線の傾きは買物回数の増減の 傾向を示しており、1より小さい場合に買物回数は減少傾向となる。 全体の傾向は、いずれのカテゴリーも前年比で減少傾向にあるもの のレストランと食品は傾き 0.674 と減少傾向が大きく、逆に、衣料 品は 0.823 と減少傾向は小さくなっている。一方で、買物回数が 5000 回未満の傾向を見ると、衣料品は傾き 0.673 と全体の傾き 0.823 と比較すると小さくなっており、一般店舗の減少傾向が大き いことがわかる。これとは逆に、雑貨は 5000 回未満の傾き 0.938 で、全体の傾き 0.800 よりも大きくなっていることから、準核店舗 の減少傾向が大きくなっていることがわかる。

以上のことから、業種によって COVID-19 の影響が異なり、業種 内でも店舗規模によって影響が異なる傾向があることが示唆された。

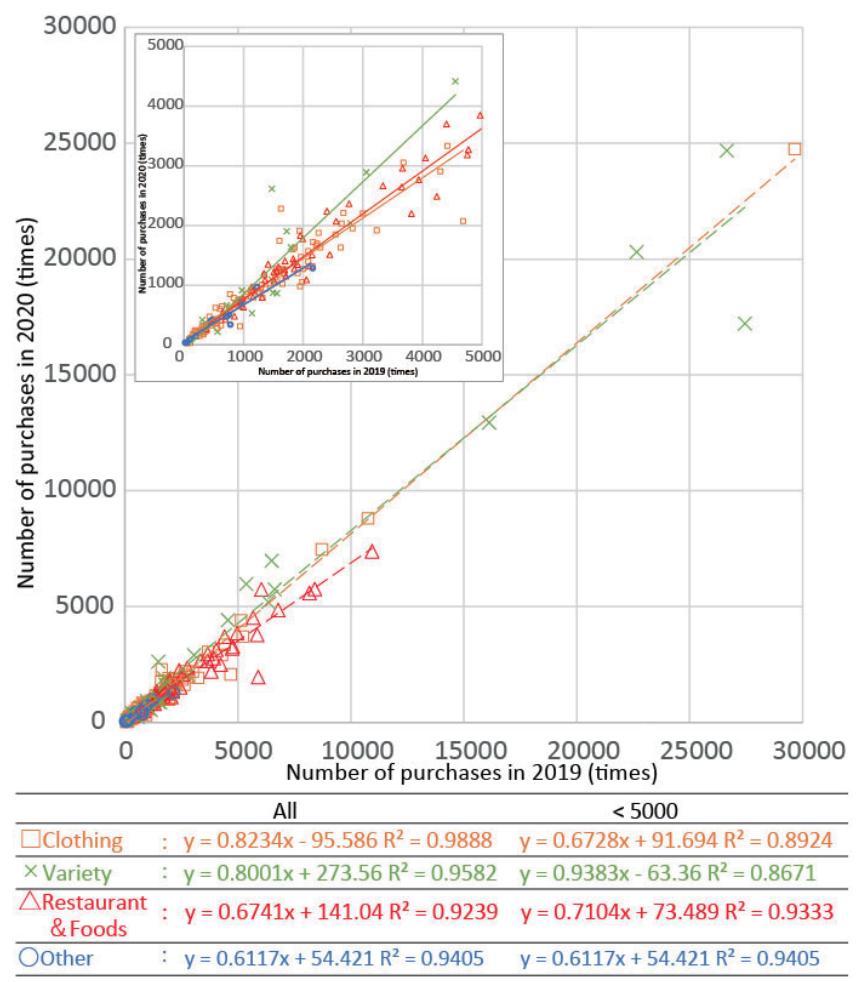

Fig. 14 Scatter diagram of the number of purchases for each store in 2019 and 2020 
Table7 Comparison table for number of transitions by floor (2019-2020)

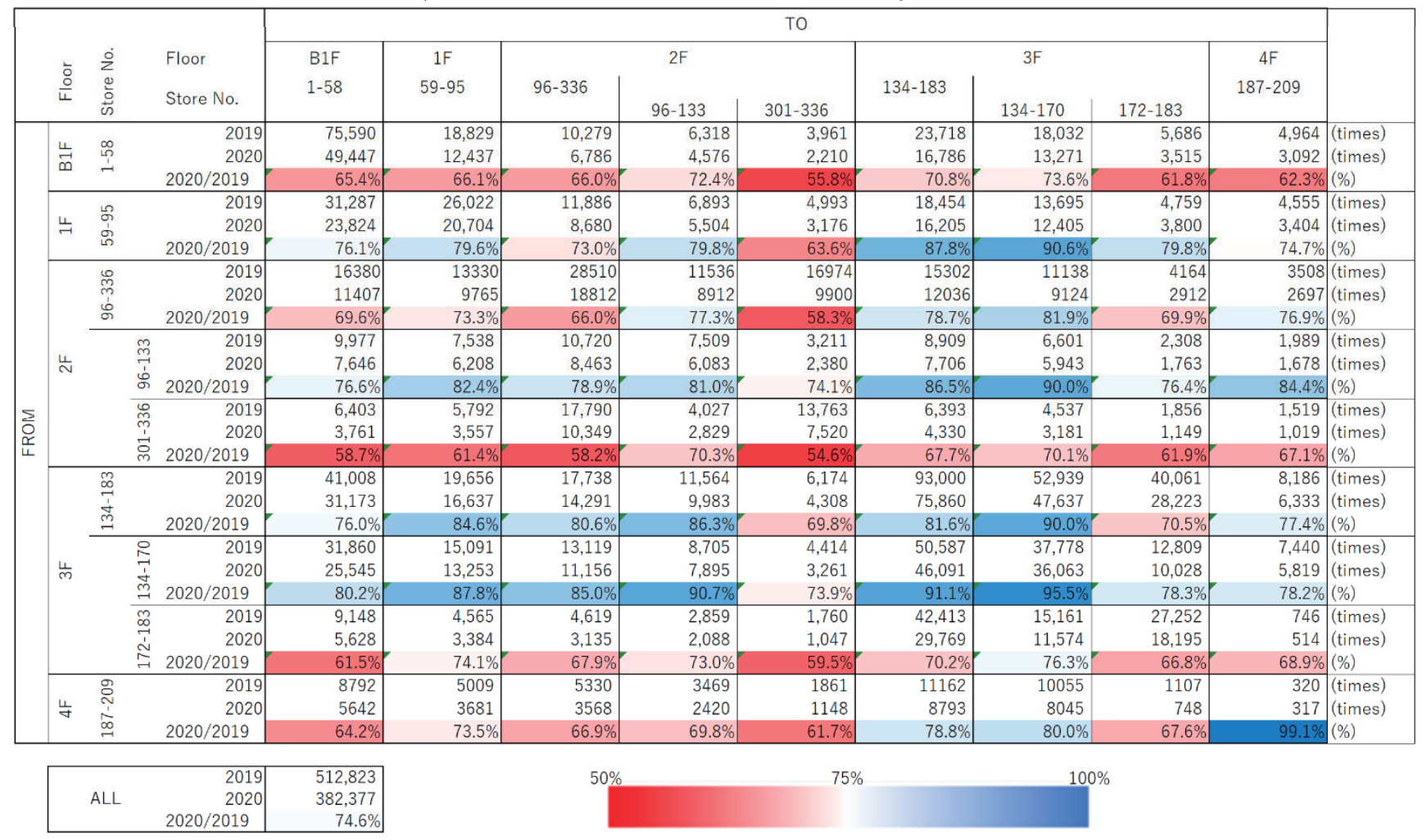

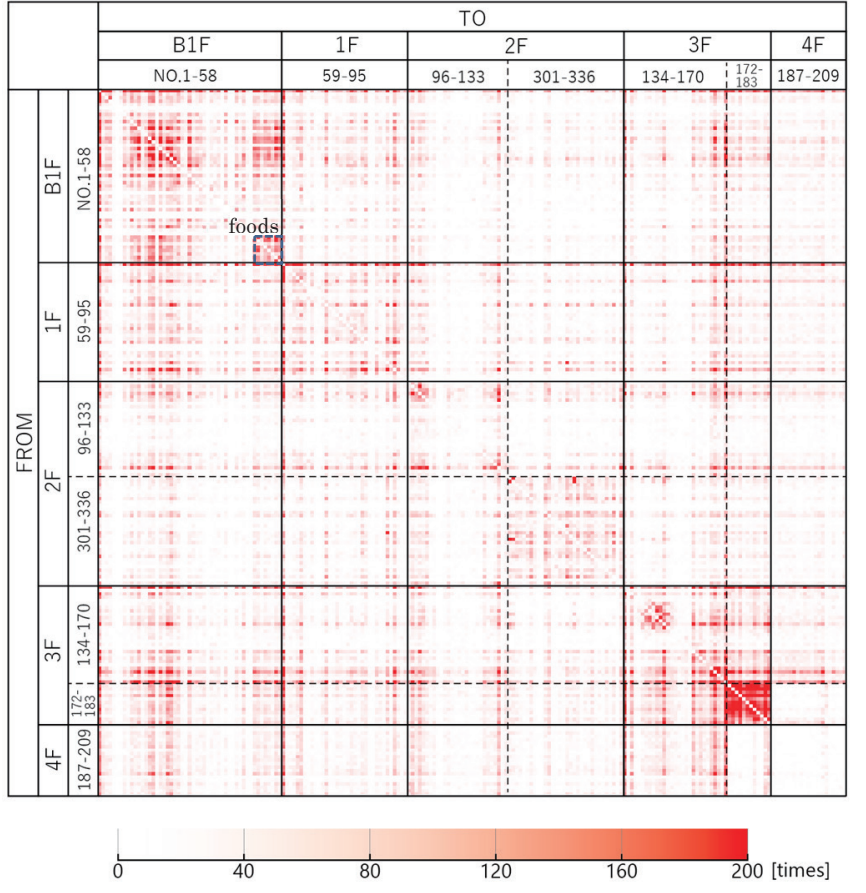

Fig. 15 Number of transitions between stores in 2019

次に、Table7 は、階毎の店舗遷移回数をまとめた表で縦に出発階、 横を目的階としており、2 階はフードコートゾーン、3 階は若者向 け衣料品ゾーンも区別した（Fig.1）。階の遷移を年度比較すると、 $2 \mathrm{~F}$ の店舗 301-336 (若者向け衣料品ゾーン) は、出発ゾーンから他 の階への遷移も他の階から目的ゾーンへの遷移の減少率も大きい。 この理由として、このゾーンが若者向けの衣料品を取り扱う店舗の 集積ゾーンであるため、比較的他の階との関連性が弱く、さらに

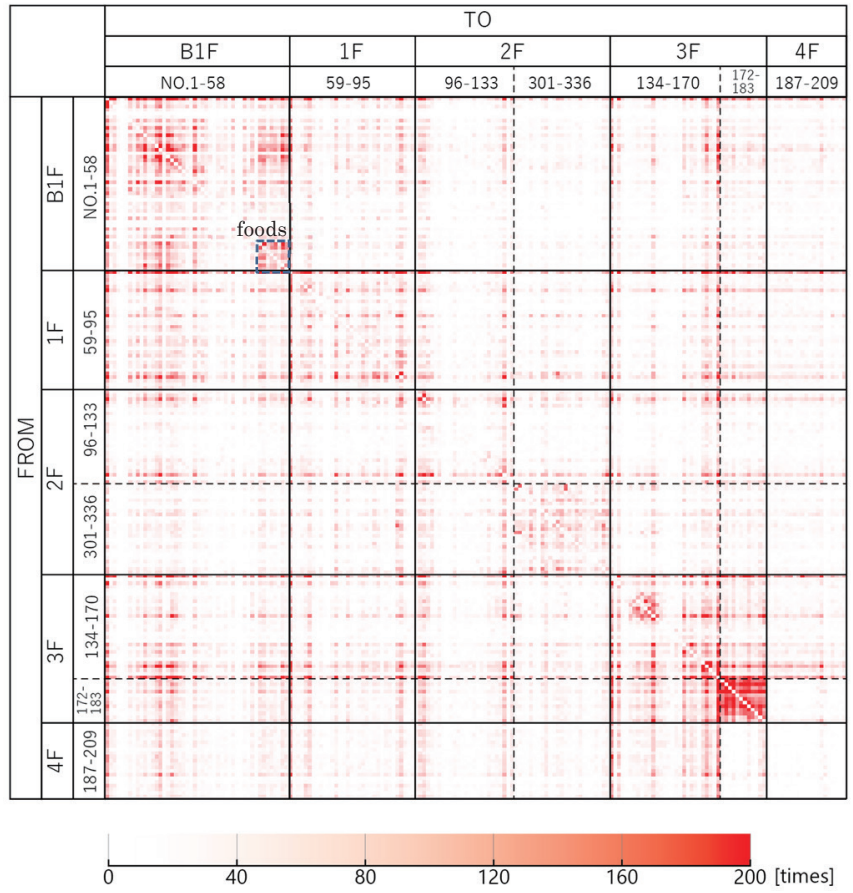

Fig. 16 Number of transitions between stores in 2020

COVID-19 の影響により、キャンペーンセール中の買い回りが自肃 されたことが考えられる。B1F、3F の店舗 172-183（フードコート ゾーン）も同様の傾向であるが、これは COVID-19 の影響で外食を 控えたり、店舗側が感染症対策により座席数を減らすなどの対応を したためと考えられる。一方、1F、2F の店舗 96-133 は他と比較す ると出発階・ゾーンから他の階への遷移も他の階から目的階・ゾー ンとなる遷移の減少率も小さくなっている。これらは、ファストフ 
アッションを扱う準核店舗を中心に衣料品を扱う店舗が多い階で、 ターゲットとなる年齢層が広いことにより、COVID-19 の影響が小 さくなったのではないかと推察される。また、3F 店舗 134-170の ゾーンも同様の傾向を示しているが、このゾーンはキッズ商品や雑 貨を扱う店舗が多く集まったゾーンであり、外出自肃の影響により、 家の中で快適に過ごすためのいわゆる巣ごもり需要が要因に考えら れる。このように、階やゾーンによって、そこに集積する業種やタ ーゲットとなる買物客属性が異なるために、COVID-19 の影響によ る遷移回数の減少率の傾向が異なっている。一方で、対象 $\mathrm{SC}$ の $2 \mathrm{~F}$ 、 $3 \mathrm{~F}$ は影響の大きいゾーンと小さいゾーンが混在し、階としての影響 が平均化され、階毎の遷移の偏りが軽減されている。

次に各店舗間の遷移について、Fig.15、16 は縦に出発店舗、横を 目的店舗とした 2019 年 (総数 512,823 回) と 2020 年(総数 382,377 回）の店舗間遷移回数表である。 2019 年 $(208 \times 208) 、 2020$ 年 $(194$ ×194）の行列を回数が少なければ白色、多ければ赤色を濃く表示し ている。店舗間遷移回数表の特性として、対角線上で赤色が濃くな っている箇所は、同一階で回遊を続ける傾向が強いことを示す。例 えば B1F の店舗 51-58 は食料品店が集積しており、2F の店舗 301336 は若者向けの衣料品店が集積している。また、 $3 \mathrm{~F}$ の店舗 172 183 はフードコートゾーンであり、店舗間遷移回数は多くなってい るが、これは家族連れなどが複数店で購入している可能性がある。 また、縦 1 列に帯状に赤色が濃くなる店舗はどの店舗からも遷移が 多いことを意味し、準核店舗などがこれにあたる。

以上の特徴は 2019 年と 2020 年の店舗間遷移回数表どちらでも 読み取ることができ、 2020 年の店舗間遷移回数は減少しているもの の全体的な傾向に大きな相違は見られなかった。ただし、店舗間遷 移回数表は、赤色の最大值を 200 回に設定している。これは、200 回未満の遷移回数の店舗ペアが両年とも $99 \%$ 以上を占めるためで ある。一方で、200 回以上の遷移回数がある店舗ペアはほとんどが 準核店舗を含むものであり、200 回以上の $1 \%$ の店舗ペアの全体に 占める遷移回数の割合は約 $30 \%$ あ。

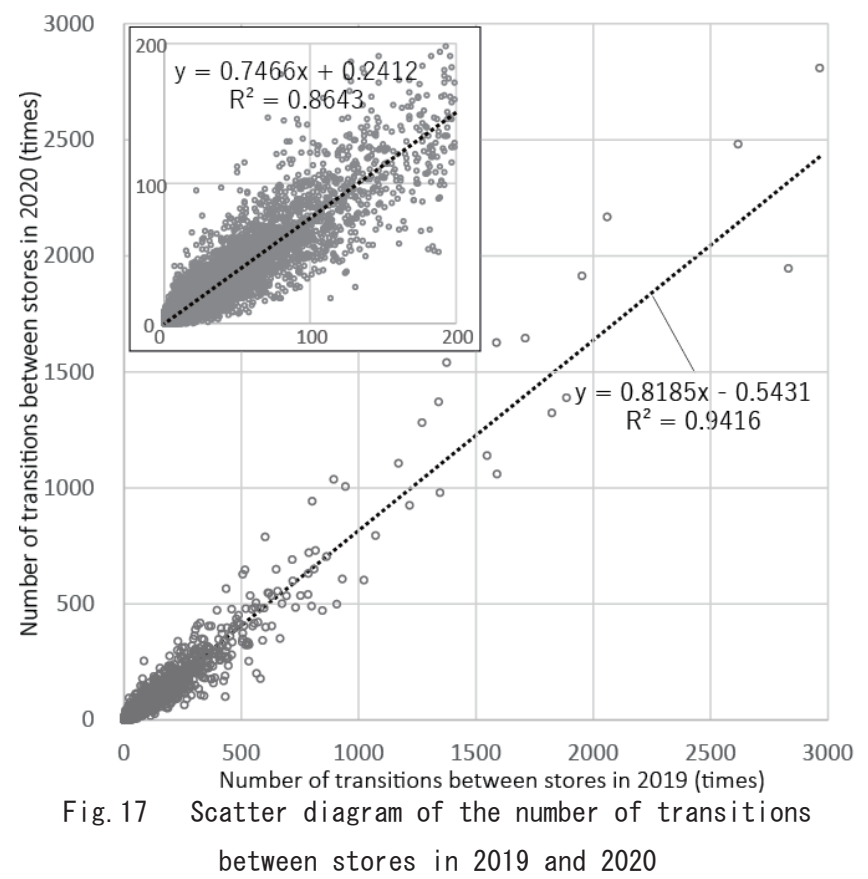

Fig.17 は、縦軸に 2020 年、横軸に 2019 年における各店舗間の 遷移回数を示した散布図である。店舗間遷移回数の多い準核店舗と それ以外の傾向を分析するため店舗間遷移回数が 200 回未満の散布 図を図の左上に拡大して表示し、回帰直線と決定係数を示した注 ${ }^{12}$ 。 図中の回帰直線の傾きは遷移回数の増減の傾向を示し、1 より小さ い場合は遷移の回数は減少傾向となる。全体の回帰直線は $\mathrm{y}=$ $0.819 \mathrm{x}-0.543\left(\mathrm{R}^{2}=0.942\right) 、 200$ 回未満の回帰直線は $\mathrm{y}=0.745 \mathrm{x}$ $+0.241 （ \mathrm{R}^{2}=0.864 ）$ であり、200 回未満の傾きの方が小さかった。 このことより、全体的な傾向としては、準核店舗は一般店舗よりも 店舗間遷移の減少傾向が小さく、COVID-19の影響を受けにくいと 考えられる。

以上より、SC 内の買物行動について、店舗間遷移回数は減少して いるものの全体的な傾向に大きな変化は見られないこと、一方で、 階やゾーンによっては、そこに集積する業種やターゲットとなる買 物客属性が異なるために、COVID-19 の影響による遷移回数の減少 率の傾向が異なっていること、対象 $\mathrm{SC} の 2 \mathrm{~F} 、 3 \mathrm{~F}$ は影響の大きい ゾーンと小さいゾーンが混在し、階としての影響が平均化され、階 毎の遷移回数の偏りが軽減されていることが明らかとなった。また、 一回の来訪における買い回り店舗数や滞在時間は COVID-19 の影 響下にある 2020 年の方が統計的に有意に減少していること、対象 施設近傍のエリアで高年齢になるほど、滞在時間の減少率が大きく、 対象施設遠方のエリアで低年齢になるほど、滞在時間の減少率は小 さくなる傾向が示された。さらに、2020 年の 7-9 月の滞在時間に は統計的に有意な差は認められず、COVID-19 の影響により対象期 間中に実施されたキャンペーンセールや夏休み期間の買物行動が制 限されている可能性が示唆された。また、衣料品の準核店舗は COVID-19の影響が小さく、一般店舗は影響が大きい。雑貨は逆に、 準核店舗は影響が大きく、一般店舗は影響が小さいなど、業種や規 模によって影響が異なることが示された。

\section{4. まとめ}

本研究は、大規模商業施設を対象として SC の会員カード購入履 歴を利用し、COVID-19 における買物行動の変化の傾向を分析する ことで以下の結果を得た。

1. 2020 年 (6-9月) は前年比で総買物回数は $83 \%$ に減少しており、 客単価は $92 \%$ へ減少であった。

2. 月毎の比較から、2020 年 6 月は緊急事態宣言の活動自肃明け で、買物客数が一旦戻ったが 2020 年 7-9 月は前年比約 $20 \%$ 減であった。

3. 年齢別の傾向では、50 代以下の年代区分では COVID-19 で買物 客数が減少傾向であるのに対して、50 代以上の年齢区分では、 ほとんど変化が見られなかった。

4. エリア別の買物客数は 2019 年と 2020 年を比較から、7-9 月 で対象施設近傍のエリアの構成割合が $2-5 \%$ 増加し、逆に遠方 のエリアは 3-4\%減少した。一方で、エリア区分と年齢区分に よる傾向の差は見られなかった。

5. 月平均来訪回数（SC）は対象施設から遠いエリアほど減少割合 が大きく、遠方のエリア $(1,2)$ は $20 \%$ 以上減少した。一方で、 月平均来訪回数（1 人）に大きな差は見られず、遠いエリアほど 買物客数の減少割合も大きく、COVID-19 の影響が大きいこと 
が示唆された。

6. 2019 年（6-9 月）と 2020 年（6-9 月）の 1 回の来訪における買 い回り店舗数および滞在時間について、マン・ホイットニーの $\mathrm{U}$ 検定した結果、いずれも有意差が認められた( $<.01)$ 。

7. 2019 年と 2020 年の 6-9 月の滞在時間について、両年の各月 についてクラスカル・ウォリス検定を行ったところ、両年とも $\mathrm{p}$ $<.01$ で䶓無仮説は棄却された。しかしながら、2019 年の各月 のペアごとの比較では、 6 月と 7 月のペア以外は有意差が認め られた（p<.01）が、2020 年では、6 月と 9 月のペアのみに有意 差が認められた $(\mathrm{p}<.01)$ 。

8. 2019 年と 2020 年の 6-9 月の滞在時間の比較から、対象施設 近傍エリアで高年齢になるほど滞在時間の減少率が大きく、遠 方エリアで低年齢になるほど滞在時間の減少率は小さくなる傾 向が見られた。

9. 2019 年と 2020 年 (6-9 月) の各店舗の買物回数は、全体的に 減少しており、カテゴリー間においてレストランと食品は大き くCOVID-19の影響を受けており、衣料品への影響は小さいこ とが示唆された。ただし、衣料品は一般店舗に比心゙淮核店舗の 影響が小さく、雑貨は一般店舗に比心゙準核店舗の影響が大きい など店舗規模で影響が異なった。

10. 2019 年と 2020 年 (6-9 月) の階・ゾーン遷移回数表から、階や ゾーンによって、そこに集積する業種やターゲットとなる買物 客属性が異なるために、COVID-19 の影響による遷移回数の減 少率の傾向が異なっていること、対象 $\mathrm{SC}$ の $2 \mathrm{~F} 、 3 \mathrm{~F}$ は影響の大 きいゾーンと小さいゾーンが混在し、階としての影響が平均化 され、階毎の遷移回数の偏りが軽減されていることが明らかと なった。

11. 2019 年と 2020 年（6-9 月）の店舗間遷移回数表から、店舗間 遷移回数は減少しているものの、遷移回数 200 回未満の店舗間 では、遷移傾向に大きな相違は見られないことが示された。

12. 2019 年と 2020 年（6-9 月）の店舗間遷移散布図から、全体的 傾向は、準核店舗は一般店舗よりも店舗間遷移の減少傾向が小 さいことが示された。

以上のことから、COVID-19 禍で買物客数や買物回数は減少し、 対象施設からの距離で買物客の構成比が変化するなど COVID-19 の影響が確認された。SC内の買物行動について、1 回の来訪におけ る買い回り店舗数や滞在時間が減少していること、滞在時間に関し ては対象施設に近く高年齢になるほど減少率が大きく、遠く低年齢 になるほど滞在時間の減少率は小さくなるなど、対象施設からの距 離と年齢による傾向に差があることが明らかとなった。また、2020 年 7-9 月の 1 ケ月当たりの滞在時間には統計的に有意な差は見ら れず、キャンペーンセールや夏休み期間の買物行動が制限されてい る可能性が示唆された。店舗間遷移に関して、全体的な傾向に大き な変化は見られないが、準核店舗は一般店舗より店舗間遷移の減少 率が小さかった。階やゾーン単位ではターゲットとなる買物客属性 に合わせた店舗が集積しているために、遷移回数の減少率の傾向が 異なるなど、COVID-19 の影響が見られた。さらに、対象 $\mathrm{SC} の 2 \mathrm{~F}$ 、 $3 \mathrm{~F}$ は影響の大きいゾーンと小さいゾーンが混在し、階としての影響 が平均化され、階毎の遷移回数の偏りが軽減されていた。このこと
は、COVID-19 の影響が少ない業種やターゲット層の店舗が集中し て配置されていると、 $\mathrm{SC}$ 内の買物行動の範囲が狭まり、密になりや すい環境が発生したり、 $\mathrm{SC}$ 内の人流の偏りが顕著になる可能性を 示唆している。本研究では、MC を利用した分析を主に行っている ため、散策行動の変化などのより詳細な店舗内の買物行動の分析に 関しては今後の課題であり、COVID-19 の影響を含む買物行動モデ ルについて検討を進めたい。

\section{謝辞}

本研究は、JST 未来社会創造事業 JPMJMI20D1 および関連不動 産会社等の助成を受けたものである。記して感謝の意を表す。

\section{参考文献}

1) Ministry of Economy, Trade and Industry: 2020 White Paper on International Economy and Trade, 2020. 7 (accessed 2021. 2. 25) 経済産業省: 令和 2 年度版通商白書, 2020.7 https://www.meti.go.jp/report/tsuhaku2020/pdf/2020_zentai.pdf（参 照 2021.2.25)

2) Japan Council of Shopping Center: Report on Annual Statistical Survey of Shopping Center Sales 2020 (Preliminary), Japan Council of Shopping Center HP (accessed 2021. 2. 25)

一般社団法人 日本ショッピングセンター協会 : SC 販売統計調査報告 2020 年年間（速報），一般社団法人 日本ショッピングセンター協会 HP (参照 2021. 2. 25) http://www.jcsc.or.jp/cat_sales/p_20210225_61242

3) Watanabe, T.: In-store Shopping Behavior and Marketing Adaptations - Collaborative Aspects between Retailers and Manufacturers -, Chikura Publishing Company, 2000.1 (in Japanese)

渡辺隆之 : 店舗内購買行動とマーケティング適応一小売業とメーカー の協働側面一, 千倉書房, 2000. 1

4) Station Consumer Research Center: EKISUMER, Vol.37, 2018. 7 (in Japanese)

駅消費研究センター : エキシューマー 特集「駅ビルの回遊行動を考え る」, Vol.37, 2018. 7

5) Nagasawa, N., Sako, T., Watanabe, H.: Shopping Behavioral Model for Large-Scale Commercial Facilities Planning, Journal of Architecture and Planning (Transactions of AIJ), Vol. 74, No. 646, pp. 2611 - 2616, 2009. 12 (in Japanese)

長澤夏子，佐古崇，渡辺仁史：大規模商業施設計画のための買い物行 動 モデル, 日本建築学会計画系論文集, 第 74 巻, 第 646 号, pp. 2611 - 2616, 2009. 12

6) Ministry of Land, Infrastructure, Transport and Tourism: Smart Planning Guide -New Town Planning Based on Individual Behavior Data-, 2018. 9 (in Japanese, accessed 2021. 2. 25)

国土交通省都市局都市計画課都市計画調査室 : スマート・プランニン グ実践の手引き〜個人単位の行動データに基づく新たなまちづくり〜 【第二版】, 2018. 9 https://www.mlit.go.jp/common/001255680.pdf (参 照 2021. 2. 25)

7) Hui, S. K., Bradlow, E. T., Fader, P. S.: Testing Behavioral Hypotheses Using an Integrated Model of Grocery Store Shopping Path and Purchase Behavior, Journal of Consumer Research, Vol.36, Issue 3, pp. 478 - 493, 2009. 10

8) Ishigaki, T., Ozawa, K.: Analysis of In-Store Space Customer's Behavior Using POS Data of Department Store, Operations Research as a Management Science Research, Vol. 50, No. 3, pp. 181 - 186, 2005. 3 (in Japanese)

石垣智徳，小沢佳奈：百貨店 POS データによる顧客の店舗内空間行 動分 析, オペレーションズ・リサーチ:経営の科学, 第 50 巻, 第 3 号, pp. 181 - 186, 2005. 3

9) Kanda, Y: Investigation of the freely available easy-to-use software 'EZR' for medical statistics, Bone Marrow Transplantation, 2013, 48, 
pp. $452-458,2012.12 .3$

10) Expert Committee on Countermeasures for Novel Coronavirus Disease (COVID-19): Status analysis and recommendations for countermeasures against novel coronavirus disease (COVID-19), 2020. 3. 19

新型コロナウイルス感染症対策専門家会議 : 新型コロナウイルス感染 症対策の状況分析・提言, 2020.3.19

注

注1） NHK の公開データおよび大阪府によると、2020 年 6 月は新規感染者 数 1 桁が続いており、都道府県境をまたぐ移動制限や営業自肃を約 2 か 月ぶりに全面解禁された。7 月以降で小規模ながら新規感染者が増加し ているものの、国は「Goto トラベル事業」を開始するなど、全国的に COVID-19 の収束が期待された。しかしながら、8 月に入ると、大阪府 は独自指標・基準となる「大阪モデル」のイエローステージ 1 の対応を 要請するなどし、8 月 21 日には病床使用率が上昇したことを受け、70 歳以上の高齢者や 40 歳以上の基礎疾患を有する者の感染リスクを減ら すことなどを理由に、イエローステージ 2 へ移行するなど、COVID-19 の再拡大への警戒措置がとられた。その後、小規模な感染者数が続くが、 11 月以降感染拡大が進み、12月 4 日には大阪府はレッドステージ 1 一 の対応を要請し、2021 年 1 月 7 日には再び首都圈の 1 都 3 県に再び緊 急事態宣言が出された。

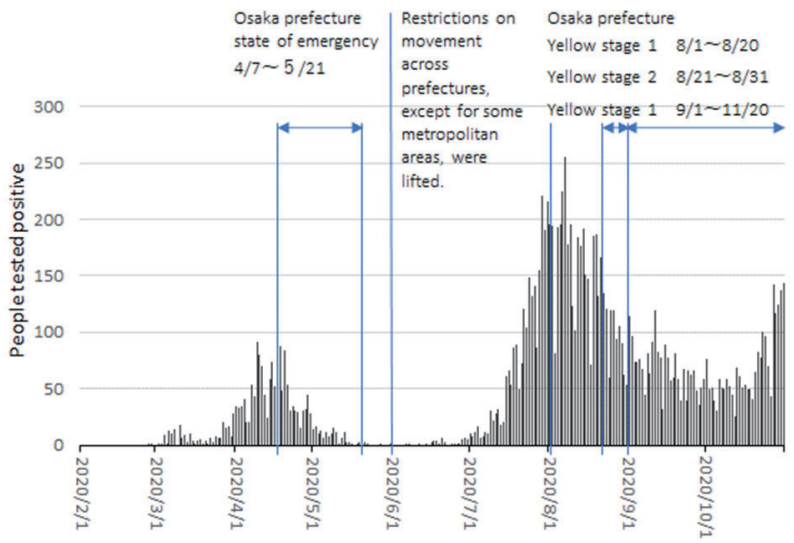

Fig. 18 Number of positive cases of COVID-19 in 0saka prefecture (dai ly)

NHK : https://www3.nhk.or.jp/news/special/coronavirus/data/ (参照 2021 .9. 10）より筆者作成。

注2） 2020 年 5 月は、緊急事態宣言の解除に合わせて、多くの店舗が同年 5 月 21 日から営業再開したため、営業日数が少なく他の月と条件が異な るため、特に断りがない限り参考值として扱い、分析に含めないことと する。また、全来館者数における MC 利用者は概衫 $20 \%$ 程度を占める。

注3）距離エリアは、行政区をもとに決定しているため、物理距離と厳密には 一致しないが、概初阿倍野区を中心とした物理距離は、エリア $5: 1.5 \mathrm{~km}$ 以下、エリア $4: 4.5 \mathrm{~km}$ 以下、エリア $3: 7.5 \mathrm{~km}$ 以下、エリア $2: 15 \mathrm{~km}$ 以下、エリア $1: 15 \mathrm{~km}$ 以上となっている。

注4）買物客数は MC の会員 ID 数のことを示し、重複はないものとする。

注5）買物回数はMC を利用した回数を示し、同じ会員 ID のものが、同一日 で複数回の場合も存在する。平均買物回数は総買物回数を買物客数で除 した值。

注6）株式会社 Agoop が実施した調査「新型コロナウイルス拡散における人 流変化の解析 2021.9.9 https://www.agoop.co.jp/coronavirus/ (参照 2021. 9. 10)」によれば、大阪駅エリアへの人流は 2019 年 9 月と 2020 年 9 月を比較して、約 $40 \%$ 減少している。また、大阪市が実施した「新 型コロナウイルスによる企業活動への影響に関する調査 2020.6.30」に よれば、調査対象企業の約 $55 \%$ がテレワークを実施・実施済みと回答 している。

注7） MC のデータに住所登録していない買物客も存在し、住所不明の買物客 は Fig.7、8 で分析に含んでいないため、図中の（）内の合計と Table2 の総買物客数は一致しない。

注8）来訪回数は MC を利用した日数と同じ。
注9）施設管理者によると、キャンペーンセールは 2019 年 7 月 10 日 - 8 月 31 日、 2020 年 7 月 10 日 -8 月 31 日で実施されたが、 2020 年は例年 よりも告知等の広報活動は少なかった。

注10) 2019 年と 2020 年の両方に店舗があった 194 店舗を対象としている。

注11) 準核店舗は、2019 年の買物回数が 5000 回以上の店舗のこと。また、買 物回数 5000 回未満の回帰直線と決定係数は 2019 年の買物回数が 5000 回未満の店舗としている。

注12) 200 回未満の店舗遷移回数の回帰直線と決定係数は 2019 年の店舗遷移 回数が 200 回未満の店舗としている。 


\title{
A STUDY ON CHANGES OF SHOPPING BEHAVIOR UNDER THE INFLUENCE OF NOVEL CORONAVIRUS INFECTION IN A LARGE-SCALE COMMERCIAL FACILITY
}

\author{
Akira TAKAHASHI ${ }^{* 1}$, Naoya OSAKA ${ }^{* 2}$, Kensuke YASUFUKU ${ }^{* 3}$ \\ and Hirokazu $A B E^{* 4}$ \\ ${ }^{*} 1$ Specially Appointed Assist. Prof. (full time), Cybermedia Center, Osaka Univ., Dr.Eng. \\ *2 Division of Global Architecture, Graduate School of Engineering, Osaka Univ., B.Eng. \\ *3 Assoc. Prof., Cybermedia Center, Osaka Univ., Dr.Eng. \\ ${ }^{*}$ Prof., Cybermedia Center, Osaka Univ., Dr.Eng.
}

The epidemic of the new coronavirus infection (COVID-19) has greatly changed people's lifestyles and common sense. Large-scale commercial facilities, including shopping centers with face-to-face sales, were greatly affected. The purpose of this study is to quantitatively understand how shopping behavior trends about the shopping center have changed due to the influence of COVID-19 by using the purchase history of membership cards in one of the large-scale commercial facilities. The subject large-scale commercial facility is a shopping center with approximately 240 stores, a total floor area of approximately $69,000 \mathrm{~m}^{2}, 4$ stories above ground and 1 story below ground. The membership card information used is for a period of five months each, from May to September 2019 and 2020. This is the purchase history data for each store and there are approximately 3.1 million total data processed. The purchase history includes 23 items: membership number, gender, age, address, store name, purchase date and time, purchase amount, etc. There are approximately 270,000 to 380,000 membership cards processed per month, and the purchase history of 80,000 to 100,000 members per month can be used. The main findings are as follows.

In 2020, under the influence of COVID-19, the number of shoppers and purchases decreased, and the number of visits decreased by more than $20 \%$ in areas far from the subject shopping center. It was also found that the proportion of shoppers close to the subject shopping centers increased, while the proportion of shoppers far from the subject decreased. Furthermore, regarding shopping behavior in shopping centers, the number of stores visited per visit and the time spent in shopping centers decreased in a statistically significant manner although there was little change in the trend of the number of trips between stores. The average length of time spent in the shopping center showed a difference in trend depending on distance from the target facility and age. In other words, the older the age in the area close to the target facility, the greater the rate (2020/2019) of decrease, and the younger the age in the farther area, the smaller the rate of decrease in time spent. On the other hand, there was no statistically significant difference in the average time spent each month in 2020 (July-September), suggesting that COVID-19 may be limiting consumer activity during campaign sales and summer vacation periods.

（2021 年 4 月 6 日原稿受理，2021 年 10 月 14 日採用決定） 